MR DANIEL J BORSUK (Orcid ID : 0000-0003-0511-8916)

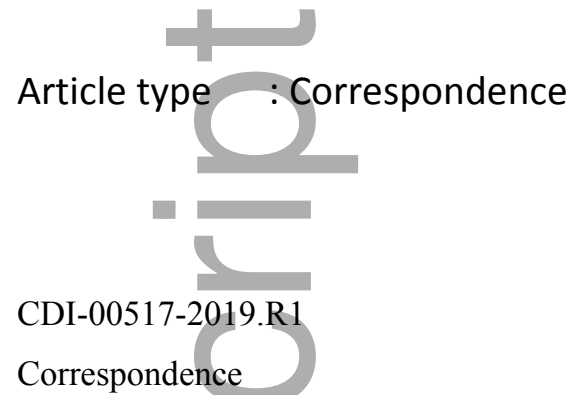

\title{
Robotic excision of a difficult retrorectal cyst - a video vignette
}

Running head: Difficult retrorectal cyst excised robotically

Daniel J. Borsuk BS ${ }^{1,3}$, Adam Studniarek MD ${ }^{1,2}$, Ahmed AL-Khamis MD ${ }^{1}$, Kunal Kochar MD ${ }^{1}$, John J. Park MD 1 , Slawomir J. Marecik MD ${ }^{1,2}$

'Division of Colon and Rectal Surgery, Advocate Lutheran General Hospital, Park Ridge, Illinois, USA;

${ }^{2}$ Division of Colon and Rectal Surgery, University of Illinois at Chicago, Chicago,

Illinois, USA;

${ }^{3}$ Department of Surgery, Michigan Medicine, University of Michigan, Ann Arbor, Michigan, USA

\section{Corresponding Author:}

Daniel J. Borsuk

LM Prasad MD SC

1550 N. Northwest Highway, Suite 107, Park Ridge, IL 60068, USA

Telephone: +1.8477591110

Facsimile: +1.8477598273

This is the author manuscript accepted for publication and has undergone full peer review but has not been through the copyediting, typesetting, pagination and proofreading process, which may lead to differences between this version and the Version of Record. Please cite this article as doi: $\underline{10.1111 / C O D I .14862}$

This article is protected by copyright. All rights reserved 


\section{Email: $\underline{\text { dborsuk@umich.edu }}$}

Conflicts of Interest: There are no conflicts of interest to declare.

\section{Acknowledgements}

No acknowledgements.

Dear Editor,

Contrary to historical teaching about addressing very distal retrorectal (presacral) cysts via perianal incision, our preferred, current method for treating most of these lesions involves a robotic abdominal approach $(1,2)$. Benefits of this approach include excellent exposure and no perianal wound creation, which tends to frequently become infected (1).

A 31-year-old female presented with a recurrent, presacral $8 \mathrm{~cm}$ cyst located at the level of the mid-lower rectum and without rectal communication. The dissection was completed as depicted in the video vignette. Robotic and assistant ports were placed as depicted in the figure. The cyst was firmly adherent to the medial aspect of the levators and the rectal wall. Flexible sigmoidoscopy was used periodically to distend and collapse the rectum, in order to visualize and transilluminate a safe dissection plane. The cyst had a very thin wall. Although a small hole was inadvertently made, we found the resultant partial decompression aided in resection by allowing for delineation of the obscure aspects of the cyst wall.

The patient's post-operative course was unremarkable. She was discharged home the next day. Pathology revealed a benign, unilocular epidermoid cyst. At fifteen months, the patient has not experienced any recurrence or anorectal complains.

Removal of the entire cyst tissue is paramount in preventing recurrence. In the deep pelvis, the robotic platform allows for excellent exposure, stability, and precise dissection in comparison to the limited ergonomics of the laparoscopy (3-5). It also allows one to avoid the perineal wound when compared to trans-levator approach (1). 


\section{Supporting information: video and transcript}

\section{References}

1. Marecik SJ, Al-Khamis A, Kochar K, Park JJ. Robotic Resection of Presacral (Retrorectal) Tumors and Waldeyer's Fascia. Dis Colon Rectum. 2018;61(7):e351-2.

2. Messick CA. Presacral (Retrorectal) Tumors: Optimizing the Management Strategy. Dis Colon Rectum. 2018 Feb;61(2):151-3.

3. Haydar M, Griepentrog K. Tailgut cyst: A case report and literature review. Int J Surg Case Rep. 2015;10:166-8.

4. Eftaiha SM, Kochar K, Pai A, Park JJ, Prasad LM, Marecik SJ. Robot-assisted approach to a retrorectal lesion in an obese female. J Vis Surg. 2016;2:59.

5. Oh JK, Yang MS, Yoon DH, Rha KH, Kim KN, Yi S, et al. Robotic resection of huge presacral tumors: case series and comparison with an open resection. J Spinal Disord Tech. 2014 Jun;27(4):E151-154.

\section{Figure: placement of trocars}

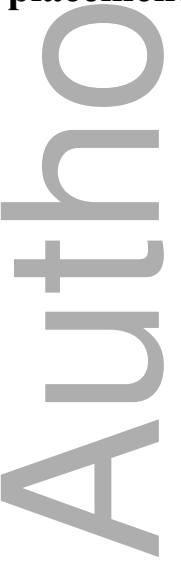




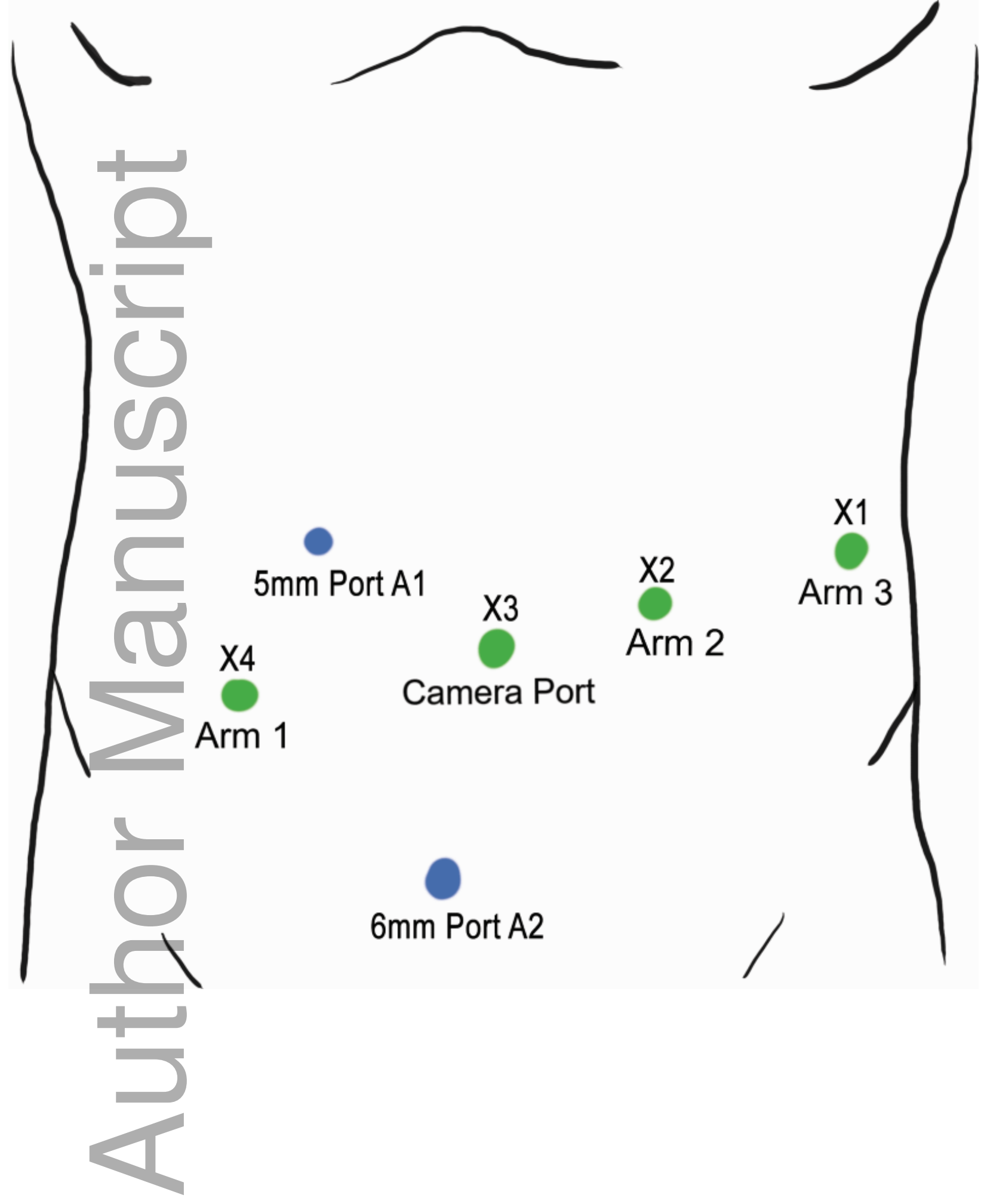




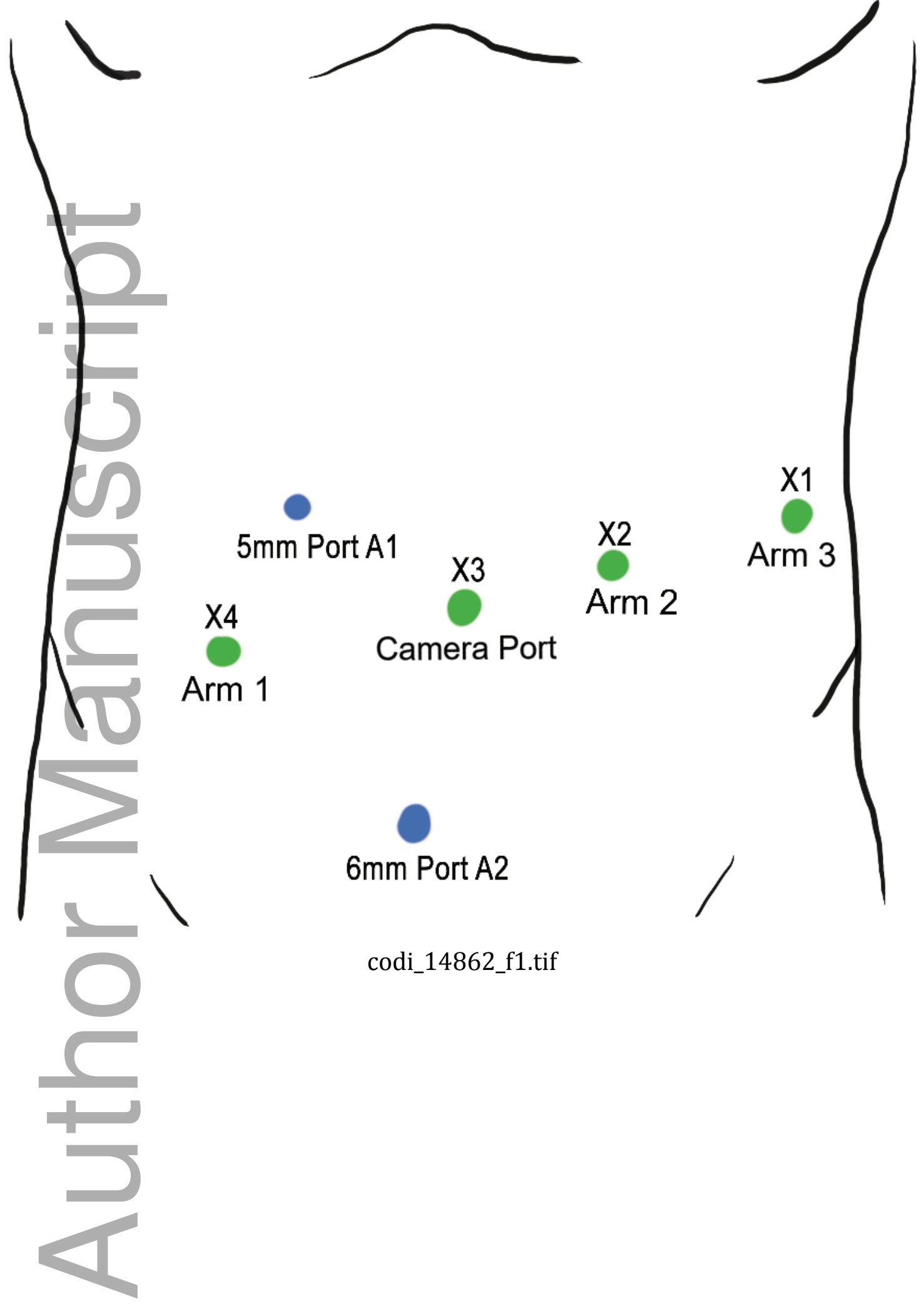

This article is protected by copyright. All rights reserved 